\title{
A Guide to the Variability of Flavonoids in Brassica oleracea
}

\author{
Vera Mageney ${ }^{1}$, Susanne Neugart ${ }^{2}$ and Dirk C. Albach ${ }^{1, *}$ \\ 1 Institute of Biology and Environmental Sciences, Carl von Ossietzky University, Oldenburg Carl von \\ Ossietzky Str. 9-11, 26129 Oldenburg, Germany; vera.mageney@uni-oldenburg.de \\ 2 Leibniz-Institute of Vegetables and Ornamental Crops Grossbeeren/Erfurt e. V., \\ Theodor-Echtermeyer-Weg 1, 14979 Grossbeeren, Germany; neugart@igzev.de \\ * Correspondence: dirk.albach@uni-oldenburg.de; Tel. +49-441-798-3339
}

Academic Editor: Maurizio Battino

Received: 16 January 2017; Accepted: 30 January 2017; Published: 8 February 2017

\begin{abstract}
Flavonoids represent a typical secondary metabolite class present in cruciferous vegetables. Their potential as natural antioxidants has raised considerable scientific interest. Impacts on the human body after food consumption as well as their effect as pharmaceutical supplements are therefore under investigation. Their numerous physiological functions make them a promising tool for breeding purposes. General methods for flavonoid analysis are well established, though new compounds are still being identified. However, differences in environmental circumstances of the studies and analytical methods impede comparability of quantification results. To promote future investigations on flavonoids in cruciferous plants we provide a checklist on best-practice in flavonoid research and specific flavonoid derivatives that are valuable targets for further research, choosing a representative species of scientific interest, Brassica oleracea.
\end{abstract}

Keywords: variation; breeding perspectives; secondary metabolites; flavonol; anthocyanidin

\section{Introduction}

Brassica oleracea comprises several crop varieties of worldwide economic importance, such as kale, broccoli, Brussels sprouts and cauliflower. In 2012 their production in the USA covered about $27 \%$ of all the acreage used for vegetable production (165,000 acres in total) [1]. Their high intraspecific variability extends to secondary metabolites produced by Brassica plants, among them glucosinolates and flavonoids [2,3]. The latter play an important role in ultraviolet (UV) protection since UV-B responsive flavonoids can reduce the risk of reactive oxygen species (ROS) generation and thereby prevent oxidative damage [4]. Therefore, the impact of flavonoids on the human body after food consumption as well as their effect as pharmaceutical supplements was discussed in several reviews [5-8]. Particularly relevant are their antioxidative activity and radical scavenging capacity [5]. So far, flavonoids are known to protect against the initiation and progression of atherosclerosis and cardiovascular disease [9]. Single flavonoid accumulation in plants through target-oriented breeding approaches as well as detailed quantification data are therefore not only of economic, but also of medical research interest. Here, we point to typical pitfalls and limitations as well as to provide a best-practice guide to generate reproducible data of high informative value.

\section{Data Comparability: Telling the Whole Story}

In nature, genotype and ecological parameters influence general phenolic contents (mostly flavonoids and hydroxycinnamic acids) and their antioxidant activity in plant tissue [10]. The necessity to consider seasonal and environmental parameters was demonstrated by numerous studies, for instance Schmidt et al. [11] and Reilly et al. [12], who found strong flavonoid variation 
with respect to tissue, year and climatic factors in addition to intercultivar variability. However, selectable parameters often remain unmentioned as well, although these specifications are easy to make and likewise necessary for further comparisons. An overview on the complexity of those selectable parameters and influencing factors is given in Figure 1.

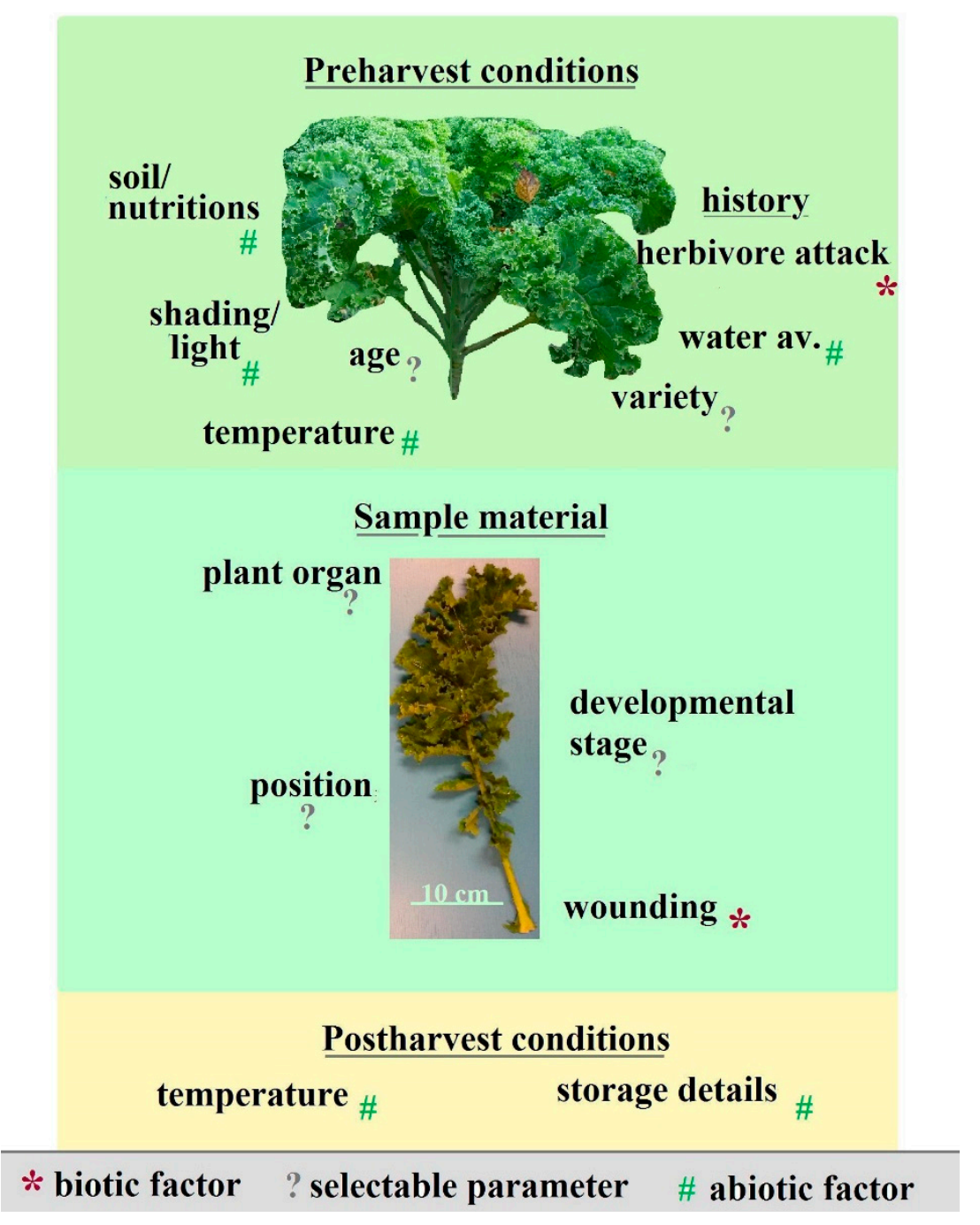

Figure 1. Overview on abiotic, biotic and selectable factors influencing the flavonoid content and composition in plants. Water av.: water availability.

Ontogenetic changes in metabolic plant profiles are well documented. Within the first two weeks of plant life, a remarkable decrease is noted regarding phenolic compounds. In Tronchuda cabbage (B. oleracea var. costata) about $11.1 \mathrm{mg}$ phenols was determined per $\mathrm{kg}$ dry weight in sprouts. Ten days later, this value had decreased by $85 \%$ [13]. Therefore, phenolic compounds are suggested to play an essential role in early plant development relevant for cell wall biosynthesis and in their function as antioxidants [13]. Later developmental stages in white (B. oleracea var. capitata) and Chinese cabbage (Brassica rapa var. pekinensis) are characterized by a significant increase in total flavonoid contents from four weeks after germination to week twelve followed by a gradual decrease [14]. However, it is not clear to what extent ontogenetic or abiotic factors determine this change. As demonstrated by Soengas et al. [15], ontogenetic differences in flavonoid production changes could also be a suitable parameter to distinguish and characterize B. oleracea varieties.

Tissue specificity of flavonoid accumulation was analysed in detail quantifying flavonoids in secondary florets, mature primary florets, immature primary florets as well as crop waste parts of 
three purple cultivars of broccoli [9]. Although great differences between plant organs were found in this study, mean "total flavonoid contents" of all three cultivars were almost alike. Considering leaf material only, Sousa et al. [16] pointed to the importance of distinguishing flavonoid profiles between external and internal leaves based on qualitative differences in flavonoid compositions as well as generally higher phenolic contents of external leaves. In accordance, the same group determined a decrease in antioxidant potential from external leaves to internal leaves of Tronchuda cabbage [17].

Injury caused either by pathogens or herbivores results in catechin and proanthocyanidin accumulation in some species [18], whereas in Arabidopsis thaliana damaged leaves show suppressed flavonoid levels [19]. The corresponding authors underline that metabolite movements through the plant initiated by herbivore feeding is often misinterpreted as local accumulation.

Light conditions also affect plants secondary metabolite profile. As demonstrated in broccoli and kale, flavonoid concentration increases with higher photosynthetic active radiation (PAR) levels [20]. Further relevant for light related changes in single flavonoid concentrations is the PAR interaction with temperature [21]. In response to UV-B radiation, qualitative as well as quantitative changes in flavonol compositions were noted [22]. Qualitative differences in flavonol ratios were found in response to low temperature conditions between 0.3 and $9.6^{\circ} \mathrm{C}$ as well, whereas no impact of low temperatures on "total flavonoid contents" was supported [11].

The effect of fertilizers on total phenolic content is contradictory discussed in the literature. Comparisons of fertilization with organic matter to conventional fertilizers (nitrogen, boron, and sulphur) imply that organic fertilization induces the acetate/shikimate pathway and therefore lead to higher flavonoid levels, whereas conventional fertilizers result in higher phenolic acid contents [16]. This effect is further supported by a field experiment on broccoli cultivars, which resulted in higher total flavonoid levels in response to organic fertilizer treatment [23]. Based on other data, organic treatment including a four-year rotation system of soil usage, organic fertilisation and winter cover crop did not lead to a significant increase in flavonoid levels [24]. Differences between the mentioned references might be caused by the choice of cultivar, as nutrition responsiveness varies among accessions [25] and distinct flavonoids chosen for quantification. Those comprised primarily catechins and luteolin [24,26], kaempferol glycoside [16] and flavonol quercetin aglycones [23], pointing to the necessity of a standard protocol to enable data comparability.

Regarding post-harvest conditions, the question on how cold storage at $1{ }^{\circ} \mathrm{C}$ affects sample material remains unanswered due to contradictory findings supporting flavonoid content preservation over several weeks [27] or pointing to a large decrease of more than $60 \%$ within the very first week [28]. Both studies concentrated on flavonol quantifications and therefore do not provide information on flavonoid metabolism in general during postharvest cooling. In contrast to the first study mentioned [27], the latter misses a clear differentiation in this regard [28]. This missing balancing act between single substance quantifications and general statements on flavonoid metabolism are unfortunately common in the literature (see Table 1). 
Table 1. Selection of previous studies and the background information given in the corresponding publications.

\begin{tabular}{|c|c|c|c|c|c|c|c|c|}
\hline Reference & $\begin{array}{l}\text { Brassica oleracea } \\
\text { Variety }\end{array}$ & Preharvest Conditions & Sample Material & & $\begin{array}{l}\text { Post-Harvest } \\
\text { Conditions }\end{array}$ & Method & $\begin{array}{l}\text { Total Flavonoid } \\
\text { Content }\end{array}$ & Flavonoids Quantified \\
\hline & Variety and Cultivar & $\begin{array}{l}\text { Age; Nutrition, } \\
\text { Light, Temperature }\end{array}$ & Plant Organ & Position \& Age & $\begin{array}{l}\text { Temperature \& } \\
\text { Storage Details }\end{array}$ & & Considered as & \\
\hline Bahorun et al. [29] & $\begin{array}{l}\text { italica cv "Packman", } \\
\text { italica cv "“ashmere" } \\
\text { capitata cv "KKCross" }\end{array}$ & $?$ & $\begin{array}{l}\text { Flower } \\
\text { Flower } \\
\text { Leaves } \\
\end{array}$ & ? & Given in detail & HPLC & $\begin{array}{l}\text { Quercetin } \\
\text { equivalents }\end{array}$ & $\begin{array}{l}\text { Myricetin, quercetin, kaempferol, apigenin } \\
\text { and luteolin aglycones after acid hydrolysis }\end{array}$ \\
\hline Heimler et al. [30] & 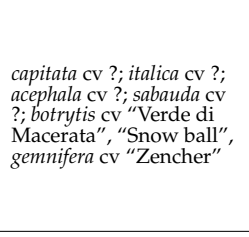 & $?$ & Edible part & $?$ & Given in detail & HPLC & $\begin{array}{l}\text { Catechin } \\
\text { equivalents }\end{array}$ & 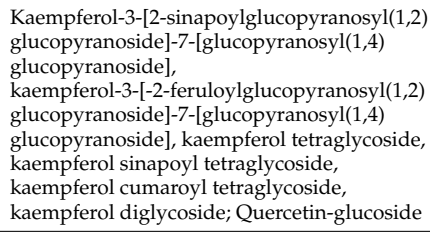 \\
\hline Jacob et al. [31] & $\begin{array}{l}\text { capitata cv?; capitata var. } \\
\text { rubra cv? }\end{array}$ & $?$ & Edible parts & ? & ? & $\begin{array}{l}\text { Spectrophotometry, } \\
\mathrm{AlCl}_{3}\end{array}$ & $\begin{array}{l}\text { Epicatechin } \\
\text { equivalents }\end{array}$ & $\begin{array}{l}\text { Method is specific for rutin, luteolin and } \\
\text { catechins (Pękal and Pyrzynska [26]) }\end{array}$ \\
\hline Jaiswal et al. [32] & $\begin{array}{l}\text { capitata f. alba cv?; } \\
\text { italica cv?; gemmifera cv? }\end{array}$ & ? & Edible parts & $\begin{array}{l}\text { Positions } \\
\text { given, ages? }\end{array}$ & ? & HPLC & $\begin{array}{l}\text { Quercetin } \\
\text { equivalents }\end{array}$ & $?$ \\
\hline Lola-Luz et al. [33] & $\begin{array}{l}\text { italica cv "Ironman" } \\
\text { and "Red Admiral" }\end{array}$ & $\begin{array}{l}\text { Three-week range, } \\
\text { Timepoints vary; } \\
\text { Given in detail }\end{array}$ & Heads/florets & ? & $\begin{array}{l}-20^{\circ} \mathrm{C}, \\
\text { two-week range }\end{array}$ & $\begin{array}{l}\text { Spectrophotometry, } \\
\mathrm{AlCl}_{3}\end{array}$ & $\begin{array}{l}\text { Catechin } \\
\text { equivalents }\end{array}$ & $\begin{array}{l}\text { Method is specific for rutin, luteolin and } \\
\text { catechins (Pẹkal and Pyrzynska [26]) }\end{array}$ \\
\hline Naguib et al. [23] & $\begin{array}{l}\text { italica cv "Calabrese", } \\
\text { "Southern star" }\end{array}$ & $\begin{array}{l}\text { ?; Given in detail; field } \\
\text { cond.; location given }\end{array}$ & Florets & ? & Given in detail & $\begin{array}{l}\text { Spectrophotometry, } \\
\mathrm{AlCl}_{3}\end{array}$ & $\begin{array}{l}\text { Quercetin } \\
\text { equivalents }\end{array}$ & $\begin{array}{l}\text { Method is specific for rutin, luteolin and } \\
\text { catechins (Pẹkal and Pyrzynska [26]) }\end{array}$ \\
\hline Reilly et al. [12] & 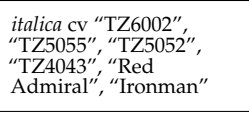 & Given in detail & $\begin{array}{l}\text { Leaf, immature Primary } \\
\text { floret, mature primary } \\
\text { floret, secondary } \\
\text { floret, flower }\end{array}$ & ? & Given in detail & $\begin{array}{l}\text { Spectrophotometry, } \\
\mathrm{AlCl}_{3}\end{array}$ & $\begin{array}{l}\text { Catechin } \\
\text { equivalents }\end{array}$ & $\begin{array}{l}\text { Method is specific for rutin, luteolin and } \\
\text { catechins (Pẹkal and Pyrzynska [26]) }\end{array}$ \\
\hline Valverde et al. [24] & $\begin{array}{l}\text { italica cv } \\
\text { "Belstar", "Fiesta" }\end{array}$ & Given in detail & Primary florets & ? & $\begin{array}{l}-20^{\circ} \mathrm{C}, \\
24-\mathrm{h} \text { range }\end{array}$ & $\begin{array}{l}\text { Spectrophotometry, } \\
\mathrm{AlCl}_{3}\end{array}$ & $\begin{array}{l}\text { Catechin } \\
\text { equivalents }\end{array}$ & $\begin{array}{l}\text { Method is specific for rutin, luteolin and } \\
\text { catechins (Pẹkal and Pyrzynska [26]) }\end{array}$ \\
\hline
\end{tabular}




\section{Dealing with Complexity}

Flavonoids are phenolic compounds containing an aromatic $\mathrm{C}_{6}$ ring bearing at least one hydroxyl group (Figure 2) [34]. Since flavonoids are generally found as glycosides in plant tissues [35] and thus are able to bind different sugar molecules to various positions, one can distinguish about 10,000 forms of flavonoids, and this number continues to increase [4]. For a single aglycone such as quercetin alone, one can find more than 170 different natural glycosides [36].

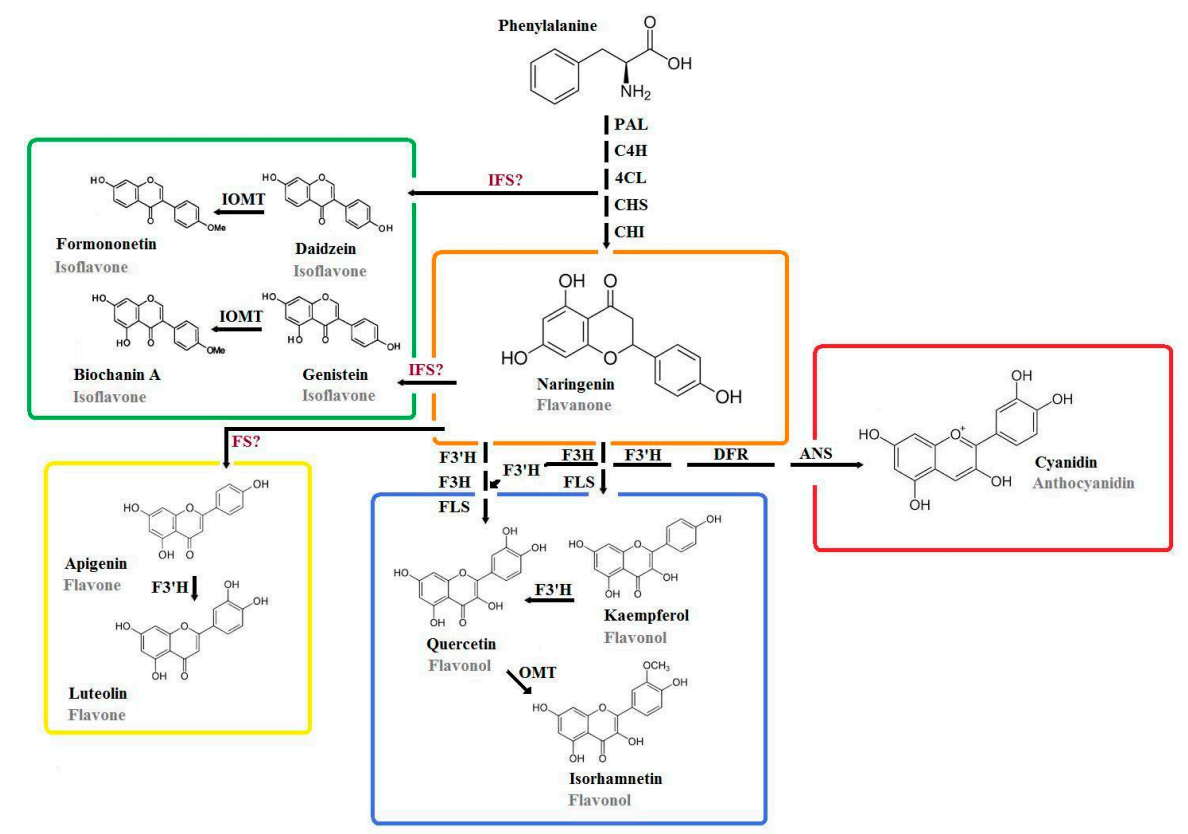

Figure 2. Simplified overview on flavonoid biosynthesis in Brassica oleracea. PAL: phenylalanine ammonialyase; $\mathrm{C} 4 \mathrm{H}$ : cinnamate-4-hydroxylase; 4CL: 4-coumarate-coenzyme A ligase; CHS: chalcone synthase; $\mathrm{CHI}$ : chalcone isomerase; IOMT: isoflavone-O-methyltransferase; IFS: isoflavone synthase; FS: flavone synthase; F3H: flavonol-3-hydroxylase; F3'H: flavonol-3'-hydroxylase; FLS: flavonol synthase; DFR: dihydroflavonol reductase; ANS: anthocyanidin synthase; OMT: O-methyltransferase.

Due to its high number of glycosidic forms, single flavonoid analyses need to be analysed aglycone- or glycoside-specific. Conflicting results can be caused by the choice of flavonoid glycosides considered in the corresponding studies. Therefore, a more general guideline is required, which gives both quantification parameters as well as potentially valuable derivatives represented in the species of interest. In B. oleracea, some flavonoid subclasses are represented in small quantities or not detectable at all, whereas other subclasses have a great potential to provide cultivar- or variety-specific flavonoid profiles.

In contrast to flavanoles and flavanones, numerous representatives of other flavonoid subclasses merit closer consideration based on previous data (Table 2). An additional approach to examine variety specific qualitative and quantitative variability of flavonols was performed by our working group (next section).

\section{Specific Flavonoids of Major Interest}

Depending on their structure, flavonoids are usually separated into six main subclasses $[37,38]$ and subcategorized within it according to their substituents (see Figure 2 for comparison) [39]. Out of these, flavanoles, characteristic of teas, red grapes and red wines, are excluded in this review since their occurrence is not supported for B. oleracea [37]. A second group, flavanones such as naringenin, are more relevant as precursors of other flavonoids in B. oleracea rather than for their direct accumulation as typical for citrus foods [37]. 
Table 2. Specific flavonoids commonly analysed in Brassica oleracea (function and intraspecific variation factor included).

\begin{tabular}{|c|c|c|c|c|c|}
\hline Flavonoid (Subclass) & Physiological Function & Relevance in Medical Research & $\begin{array}{l}\text { Content in B. oleracea [Method; } \\
\text { Variety] }\end{array}$ & Intraspecific Variation Factor & References \\
\hline Apigenin and luteolin (Flavone) & $\begin{array}{l}\text { Nodulation and general } \\
\text { defence mechanisms } 1 \\
\text { Resistance to mycorrhization }{ }^{2}\end{array}$ & $\begin{array}{l}\text { Phytoestrogen with antibacterial and } \\
\text { anti-inflammatory functions; } \\
\text { apoptosis-inducer }{ }^{3}\end{array}$ & $\begin{array}{l}\text { Occurrence contradictory } \\
\text { discussed }^{4-6} ; \sim 3-30 \mathrm{mg} / \mathrm{kg} \mathrm{fw} \\
\text { [HPLC; } \text { alba, botrytis, capitata] }^{7}\end{array}$ & Apigenin $\sim 2$ Luteolin $\sim 2.5^{7}$ & $\begin{array}{l}{ }^{1} \text { Winkel-Shirley [40] } \\
{ }^{2} \text { Ponce et al. [41] } \\
{ }^{3} \text { Martens and Mithöfer [42] } \\
\text { 4-6 Bahorum et al. [29]; } \\
\text { Sakakibara et al. [43]; } \\
\text { Miean and Mohamed [44] } \\
{ }^{7} \text { Cao et al. [45] }\end{array}$ \\
\hline Cyanidin (Anthocyanidin) & $\begin{array}{l}\text { Pigmentation of flowers and } \\
\text { fruits for recruitment of } \\
\text { pollinators and seed dispersers } 1\end{array}$ & $\begin{array}{l}\text { Antioxidant, anti-inflammatory, } \\
\text { antimicrobial \& anticarcinogenic } \\
\text { activities, positive effect on visual } \\
\text { performance \& neuroprotection }{ }^{2}\end{array}$ & $\begin{array}{l}23 \text { cyanidin derivative forms }[\mathrm{HPLC} ; \\
\text { capitata f rubra] }{ }^{3} ; \sim 40-750 \mathrm{mg} / \mathrm{kg} \text { fw } \\
{\left[\text { HPLC; } \text { botrytis; capitata f rubra] }^{4}\right.}\end{array}$ & $\begin{array}{l}\text { 18; qualitative dominance shift in } \\
\text { derivative forms }{ }^{4}\end{array}$ & $\begin{array}{l}1 \text { Winkel-Shirley [40] } \\
{ }^{2} \text { Erdman et al. [9] } \\
3 \text { Wu and Prior [46] } \\
{ }^{3} \text { Scalzo et al. [47] }\end{array}$ \\
\hline $\begin{array}{l}\text { Daidzein, genistein, glycitein, } \\
\text { biochanin A and } \\
\text { formononetin (Isoflavone) }\end{array}$ & $\begin{array}{l}\text { Root bacteria interaction } \\
\text { including symbionts and } \\
\text { pathogenic microorganism }{ }^{1}\end{array}$ & $\begin{array}{l}\text { Suggested to exert coronary benefits, } \\
\text { directly reduce atherosclerosis and lower } \\
\text { LDL-cholesterol }^{2}\end{array}$ & $\begin{array}{l}\text { Max } 10 \mu \mathrm{g} / 100 \mathrm{~g} \mathrm{fw} \\
\text { [LC/MS/MS; botrytis; capitata; capitata } \\
\text { falba; capitata f rubra; italica; gemmifera; } \\
\text { sabellica; ;aubada] }\end{array}$ & 13 (for all listed isoflavones together) ${ }^{3}$ & $\begin{array}{l}1 \text { Philips and Kapulnik [48] } \\
2 \text { Erdman et al. [9] } \\
{ }^{3} \text { Kuhnle et al. [49] }\end{array}$ \\
\hline Kaempferol (Flavonol) & $\begin{array}{l}\text { Prevent oxidative stress in chloroplasts } \\
{ }^{;} \text {, ROS reduction }{ }^{1} ; \text { photoprotection }{ }^{1} ; \\
\text { free radical scavenging capacity }^{2}\end{array}$ & $\begin{array}{l}\text { Prevents coronary heart disease and } \\
\text { chronic inflammation, suppresses cell } \\
\text { proliferation in gut cancer lines, } \\
\text { atherosclerosis prevention and growth } \\
\text { inhibition of bacteria lines (gram-positive } \\
\text { and gram-negative bacteria) }{ }^{2}\end{array}$ & $\sim 60 \mathrm{mg} / 100 \mathrm{~g} \mathrm{fw}$ [HPLC; sabellica] ${ }^{4}$ & $\begin{array}{l}\text { Qualitative dominance shift in } \\
\text { glycosides }^{2} \text {; ontogenetic dependent } \\
\text { variation }^{2} \text { ith subgroup specific } \\
\text { patterns }^{3}\end{array}$ & $\begin{array}{l}{ }^{1} \text { Pollastri and Tattini [35] } \\
{ }^{2} \text { Cartea et al. [8] } \\
{ }^{3} \text { Soengas et al. [15] } \\
{ }^{4} \text { Olsen et al. [50] }\end{array}$ \\
\hline Quercetin (Flavonol) & $\begin{array}{l}\text { See kaempferol; chelate transition metal } \\
\text { ions, auxin gradient regulation }{ }^{1}\end{array}$ & See kaempferol & $\sim 45 \mathrm{mg} / 100 \mathrm{~g} \mathrm{fw}$ [HPLC; sabellica ${ }^{4}$ & $\begin{array}{l}\text { Qualitative dominance shift in } \\
\text { derivative forms }{ }^{2} \text {; ontogenetic } \\
\text { dependent variation with subgroup } \\
\text { specific patterns }{ }^{3}\end{array}$ & $\begin{array}{l}1 \text { Pollastri and Tattini [35] } \\
{ }^{2} \text { Cartea et al. [8] } \\
3 \text { Soengas et al. [15] } \\
{ }^{4} \text { Olsen et al. [50] }\end{array}$ \\
\hline
\end{tabular}

Fw: fresh weight; LDL-cholesterol: low-density lipoprotein cholesterol; ROS: reactive oxygen species; LC/MS/MS: liquid chromatography tandem mass spectrometry; Superscripts in each row refer to the corresponding reference. 


\section{Compound Ratios as Plant Character}

Our own investigations including 28 cultivars of kale (B. oleracea var. sabellica) considered main glycosides of the flavonols kaempferol (11 glycosides considered) and quercetin (5 glycosides considered) (see also Supplemental Material). Categorization according to geographical origin or morphological characteristics such as red leaf colour did not provide any significant differences between cultivars. Instead, we found a high variability in single contents and quercetin-to-kaempferol $(\mathrm{Q} / \mathrm{K})$ ratios. More precisely, $\mathrm{Q} / \mathrm{K}$ ratios varied from 0.11 in cultivar "Winnetou" to 2.31 in "Jellen $\times$ Schattenburg" (Figure 3). Previous data based on eight kale cultivars reported half of that variation from 0.17 in "Frostara" to 1.02 in "Redbor" [11]. This great variability in Q/K ratios is a promising tool to optimize kale cultivar antioxidant activity inasmuch as quercetin provides higher activity than kaempferol [51,52].

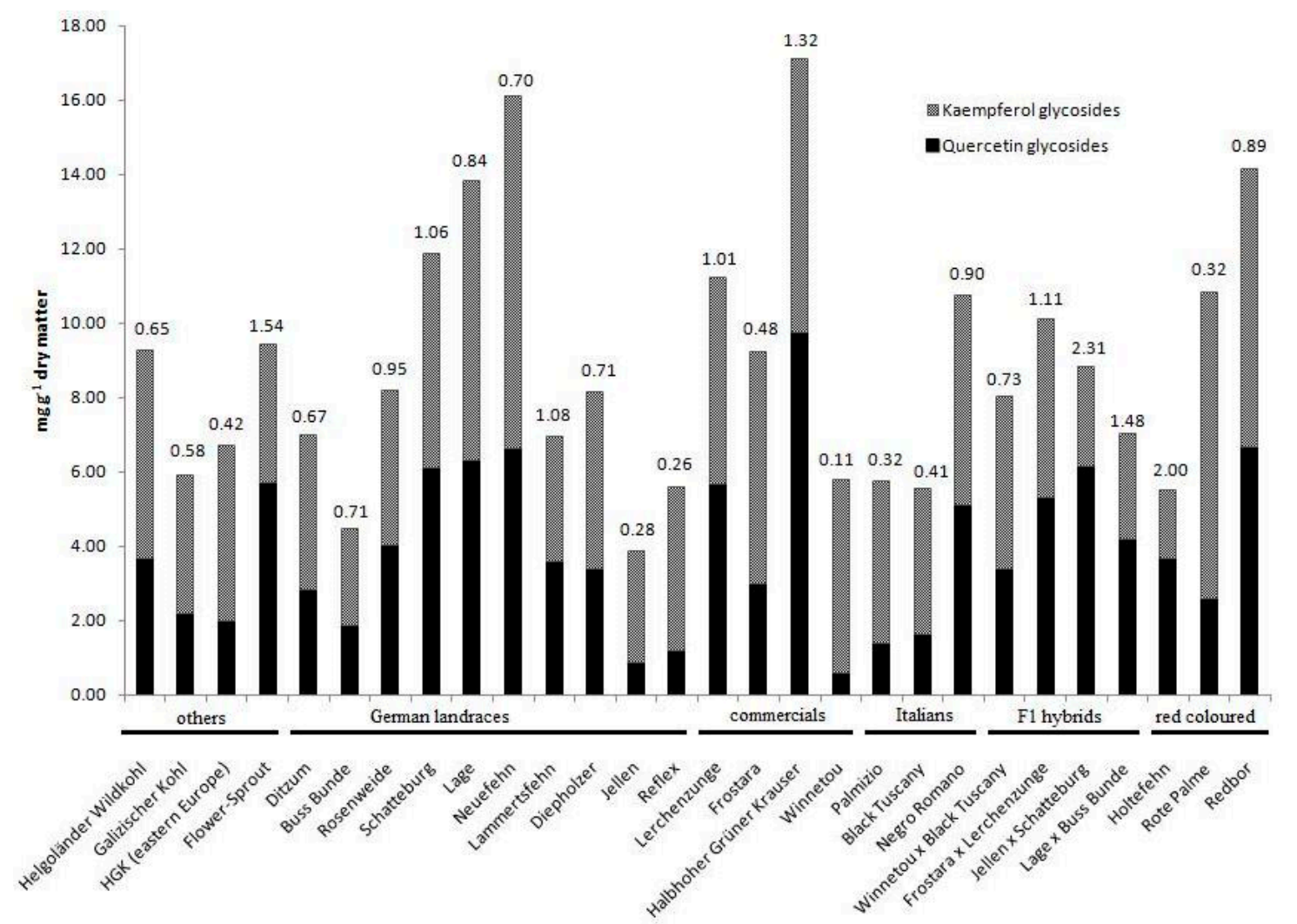

Figure 3. Quercetin and kaempferol glycoside contents and ratios (above bars) quantified in kale cultivars (Brassica oleracea convar. acephala var. sabellica) via HPLC-MS analyses. HGK: "Halbhoher grüner Krauser". Materials and methods are given in the Appendix A.

The main flavonol glycosides of kale, as for other Brassica oleracea varieties, are non-acylated and acylated kaempferol glycosides [53-55]. Our intercultivar comparison supports high variability in these kaempferol glycosides, underlining the importance of investigating a large number of different cultivars before defining subgroup specific patterns (Figure 4). In all cultivars the monoacylated kaempferol-3-O-sinapoyl-sophoroside-7-O-glycoside was the main kaempferol glycoside, followed by either the monoacylated kaempferol-3-O-feruloyl-sophoroside-7-O-glycoside or non-acylated kaempferol-3-O-sophoroside-7-O-glycoside. However, some cultivars contained high concentrations of the monoacylated kaempferol-3-O-caffeoyl-sophoroside-7-O-glycoside (e.g., "Frostara" or "Winnetou") and kaempferol-3-O-hydroxyferuloyl-sophoroside-7-O-glycoside (e.g., "Lage", "Neufehn", "Lerchenzunge" or "Halbhoher grüner Krauser"). The acylated hydroxycinnamic acids of both compounds are characterized by a catechol structure that 
was shown to be important in kale's response to UV-B [55]. Especially, the monoacylated kaempferol-3-O-caffeoyl-sophoroside-7-O-glycoside seems to be important for kale under high PAR and UVB radiation conditions [55,56]. However, based on on-line TEAC (Trolox Equivalent Antioxidant Capcity) data, kaempferol-3-O-caffeoyl-sophoroside-7-O-glycoside kaempferol-3-O-feruloyl-sophoroside-7-O-glycoside and kaempferol-3-O-hydroxyferuloyl-sophoroside7-O-glycoside contribute equally to the antioxidant activity of kale [10].

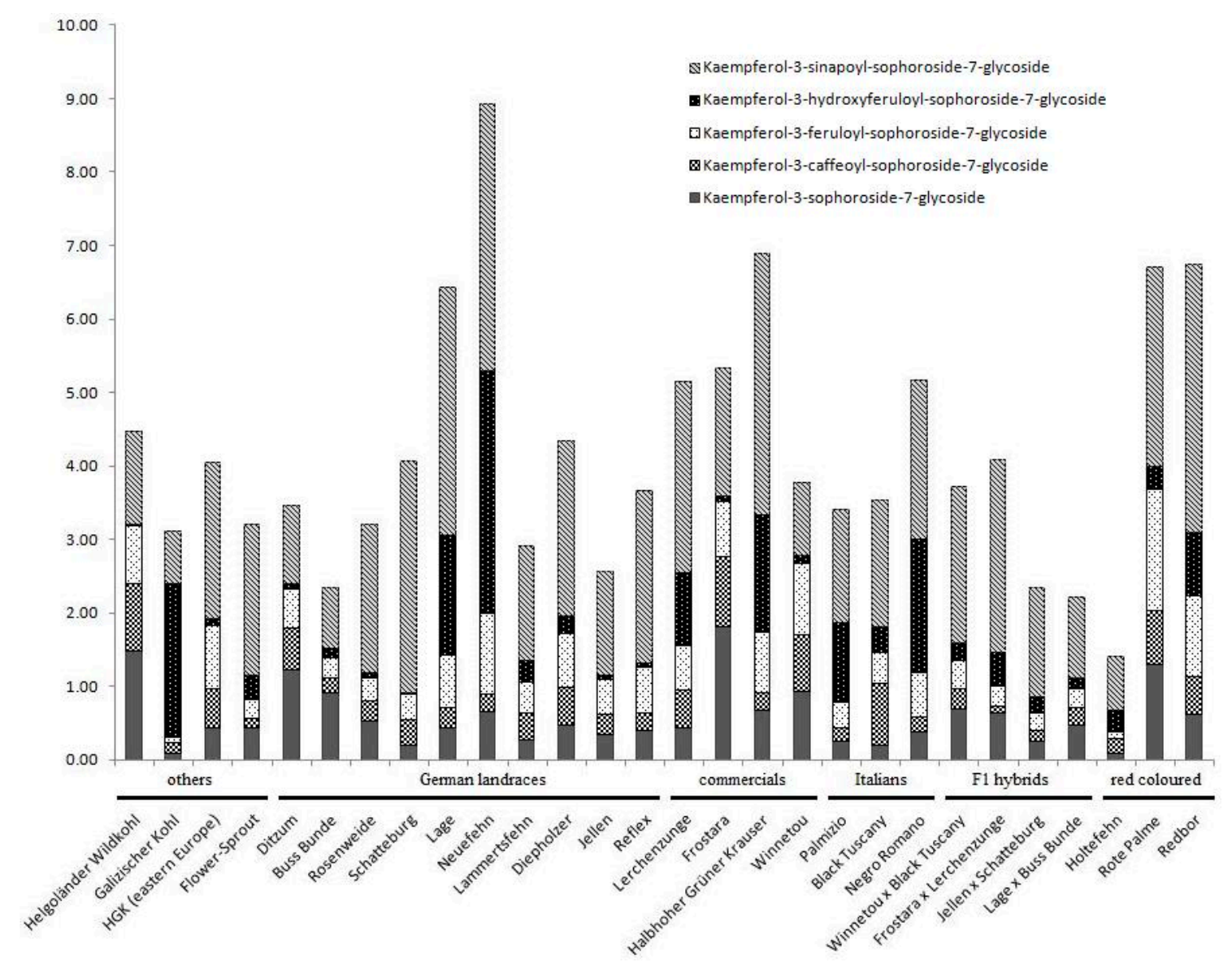

Figure 4. Kaempferol 7-glycoside contents quantified in kale cultivars (Brassica oleracea var. sabellica) via HPLC-MS analyses. Materials and methods are given in the Appendix A.

Intercultivar differences in single and total anthocyanin contents were reported by numerous studies such as [57]. Our own study demonstrated that three derivative forms (cyanidin-3-(sinapoyl)-(sinapoyl)diglycoside-5-glycoside; cyanidin-3-(sinapoyl)-(feruloyl)diglycoside5-diglycoside and cyanidin-3-(sinapoyl)(feruloyl)diglycoside-5-glycoside) were present exclusively in cultivars with red leaves or stems.

All these results support the assumption of great flavonoid variability within B. oleracea varieties, which complicates their differentiation based on flavonoids. Nevertheless, they also highlight the great potential of target-oriented breeding for flavonoid composition and content optimization. Thus, against our expectations we did not find any significant difference between specific cultivar subsets based on geography or morphological characteristics in case of flavonols, but anthocyanidins specific for red coloured accessions.

\section{Future Perspectives}

Due to the economic and scientific importance of B. oleracea and its nutritional value, comparisons are often made between edible plant parts under harvest conditions $[30,45,49]$. While such comparisons 
are understandable from a nutritional point of view, they are not useful for direct comparisons between B. oleracea varieties, because they blur varietal differences with those based on different harvest times or different plant tissues. Moreover, lots of parameters necessary for data reproduction or comparisons were often neglected or unmentioned, which impedes progress in flavonoid research. Another factor varying between previous studies is the choice of quantification method. Sophisticated techniques such as high-performance liquid chromatography (HPLC) are recommended here for further analyses on variety differentiation. A detailed overview on its handling, advantages and limits as well as suitable alternatives is given by Julkunen-Tiitto et al. [58]. This review also provides further information on sample handling and discusses current technical problems in flavonoid quantification.

Unfortunately, one issue cannot be solved by any quantification technique: the impossibility of quantifying total flavonoid contents. This is caused by the lack of available standards, the great number of different flavonoid compounds as well as the complexity of its derivative forms [58]. Measurements on a defined set of flavonoids are insufficient to make general statements on total flavonoid contents. Consequently, comparability can only be guaranteed given a clear and well defined set of substances. The choice of flavonoids and derivative forms naturally depends on the question of interest. Quantification and identification of anthocyanins have a great potential for cultivar differentiation [59] as well as variety identification and separation [47]. For example, our own investigations on kale included three glycosides, which were almost exclusively found in red coloured cultivars (see above). Furthermore, identification and quantification of flavonols quercetin and kaempferol are recommended for cultivar differentiation [11], variety identification and separation $[8,15,60]$, as well as investigations on seasonal variation [3] and influence of cooking conditions [60]. Quantification of isorhamnetin is recommended for differentiation of varieties [15], as well as for investigations in cooking conditions [60]. In accordance with others, our results support cultivar specific variation in $\mathrm{Q} / \mathrm{K}$ ratios and single flavonol glycoside contents [11]. Flavone quantification and identification are recommended in case of apigenin and luteolin, although it is yet unclear if they show any ontogenetic, seasonal or cultivar specific variation due to the sparse and contradicting remarks in the literature [29,43-45]. From our point of view, flavone quantification is of potential interest for variety as well as cultivar differentiation. Recommendations for standard selections in flavones are given by Lin et al. [54]. Finally, analyses on isoflavones such as daidzein and genistein are potentially useful for identification and separation of varieties [49,61]. As an example of more detailed investigations on isoflavones see Lapcik et al. [62], who used five isoflavone specific enzyme-linked immunosorbent assays (ELISAs) after HPLC sample fractionation to identify isoflavones in Arabidopsis.

To facilitate the selection of derivatives, we present a list of potential meaningful flavonoid glycosides for chemotaxonomic analyses on B. oleracea regarding anthocyanins as well as flavonols kaempferol and quercetin (see Table 3A,B). Future investigations may find other compounds equally suited for subgroup identification or reduce the list. However, there is promising evidence that these compounds are sufficiently variable to provide a means to distinguish between B. oleracea varieties. Furthermore, this set of flavonoids is suitable to guide in the choice of cultivars for target-oriented breeding and will improve future data comparability.

Table 3. List of potentially useful flavonoid derivatives for chemotaxonomic analyses on Brassica oleracea. A-Anthocyanins; B-Flavonols. Absence and presence partly suggested to be variety specific.

\begin{tabular}{cc}
\hline \multicolumn{3}{c}{ A-Anthocyanins } \\
\hline Anthocyanins (C-Cyanidin) & B. oleracea Variety Verification $^{\text {A- }}$ \\
\hline C-3-(caffeoyl)-( -coumaroyl)-diglycoside-5-glycoside & var. capitata f. rubra $^{3}$ \\
\hline C-3-(caffeoyl)-diglycoside-5-glycoside & var. capitata f. rubra $^{3}$ \\
\hline C-3-(caffeoyl)-diglycoside-5-glycoside & var. capitata f. rubra $^{3}$ \\
\hline
\end{tabular}


Table 3. Cont.

\begin{tabular}{|c|c|}
\hline \multicolumn{2}{|c|}{ A-Anthocyanins } \\
\hline Anthocyanins (C-Cyanidin) & B. oleracea Variety Verification \\
\hline C-3-(feruloyl)-(feruloyl)-diglycoside-5-glycoside & var. capitata f. rubra ${ }^{3}$ \\
\hline C-3-(feruloyl)-diglycoside-5-glycoside & $\begin{array}{l}\text { var. botrytis itálica }{ }^{1} \\
\text { var. capitata f. rubra }{ }^{3}\end{array}$ \\
\hline C-3-(glycopyranosyl)-(feruloyl)-diglycoside-5-glycoside & var. capitata f. rubra ${ }^{3}$ \\
\hline C-3-(glycopyranosyl)-(sinapoyl)-diglycoside-5-glycoside & var. capitata f. rubra ${ }^{3}$ \\
\hline C-3-(p-coumaroyl)-(sinapoyl)-diglycoside-5-(malonyl)-glycoside & var. botrytis italic ${ }^{1}$ \\
\hline C-3-( $p$-coumaroyl)-(sinapoyl)-diglycoside-5-glycoside & $\begin{array}{l}\text { var. botrytis itálica }^{1} \\
\text { var. capitata f. rubra }{ }^{3}\end{array}$ \\
\hline C-3-(p-coumaroyl)-diglycoside-5-glycoside & var. botrytis italic ${ }^{1}$ \\
\hline C-3-(p-hydroxybenzoyl)-(oxaloyl)-diglycoside-5-glycoside & var. capitata f. rubra ${ }^{3}$ \\
\hline C-3-(sinapoyl)-(feruloyl)-diglycoside-5-(malonyl)-glycoside & var. botrytis italic ${ }^{1}$ \\
\hline C-3-(sinapoyl)-(feruloyl)-diglycoside-5-glycoside & $\begin{array}{c}\text { var. botrytis itálica }^{1} \\
\text { var. capitata f. rubra } \\
\text { var. sabellica }\end{array}$ \\
\hline C-3-(sinapoyl)-(sinapoyl)-diglycoside-5-(malonyl)-glycoside & var. botrytis italic ${ }^{1}$ \\
\hline C-3-(sinapoyl)-(sinapoyl)-diglycoside-5-glycoside & $\begin{array}{c}\text { var. botrytis itálica }^{1} \\
\text { var. capitata f. rubra } \\
\text { var. sabellica }^{4}\end{array}$ \\
\hline C-3-(sinapoyl)-diglycoside-5-(sinapoyl)-glycoside & var. capitata f. rubra ${ }^{3}$ \\
\hline C-3-(sinapoyl)-diglycoside-5-glycoside & $\begin{array}{l}\text { var. botrytis itálica }{ }^{1} \\
\text { var. capitata f. rubra }{ }^{3}\end{array}$ \\
\hline C-3-(sinapoyl)-diglycoside-5-xyloside & var. capitata f. rubra ${ }^{3}$ \\
\hline C-3-(sinapoyl)-glycoside-5-glycoside & var. capitata f. rubra ${ }^{3}$ \\
\hline C-3-(sinapoyl)-triglycoside-5-glycoside & var. botrytis italic ${ }^{1}$ \\
\hline C-3,5-diglycoside & $\begin{array}{l}\text { var. botrytis itálica }{ }^{1} \\
\text { var. capitata f. rubra }{ }^{3}\end{array}$ \\
\hline C-3-diglycoside & var. capitata f. rubra ${ }^{3}$ \\
\hline C-3-diglycoside-5-glycoside & $\begin{array}{l}\text { var. botrytis itálica }{ }^{1} \\
\text { var. capitata f. rubra }{ }^{3}\end{array}$ \\
\hline C-3-diglycoside-5-xyloside & var. capitata f. rubra ${ }^{3}$ \\
\hline C-3-(6-feruloyl)-sophoroside-5-(6-sinapyl)-glycoside & var. botrytis ${ }^{2}$ and var. capitata ${ }^{2}$ \\
\hline C-3-(6-feruloyl)-sophoroside-5-glycoside & var. botrytis ${ }^{2}$ and var. capitata ${ }^{2}$ \\
\hline C-3-(6-p-coumaryl)-sophoroside-5-(6-sinapyl)-glycoside & var. botrytis ${ }^{2}$ and var. capitata ${ }^{2}$ \\
\hline C-3-(6-p-coumaryl)-sophoroside-5-glycoside & var. botrytis ${ }^{2}$ and var. capitata ${ }^{2}$ \\
\hline C-3-(6-sinapyl)-sophoroside-5-(6-sinapyl)-glycoside & var. botrytis ${ }^{2}$ and var. capitata ${ }^{2}$ \\
\hline C-3-(6-sinapyl)-sophoroside-5-glycoside & var. botrytis ${ }^{2}$ and var. capitata ${ }^{2}$ \\
\hline C-3-glycoside-5-glycoside & var. capitata ${ }^{2}$ \\
\hline C-3-sophoroside-5-glycoside & var. botrytis ${ }^{2}$ and var. capitata ${ }^{2}$ \\
\hline \multicolumn{2}{|c|}{ B-Flavonols } \\
\hline Flavonol (Q-Quercetin; K一Kaempferol) & $\begin{array}{l}\text { B. oleracea Variety Verification } \\
\text { (as Reviewed by Cartea et al. [8]) }\end{array}$ \\
\hline Q-3-O-sophorotrioside-7-O-sophoroside & var. acephala, var. botrytis italica \\
\hline Q-3-O-sophorotrioside-7-glycoside & var. acephala, var. botrytis italica \\
\hline Q-3-O-sophoroside-7-O-glycoside & $\begin{array}{c}\text { var. capitata f. alba, var. acephala, } \\
\text { var. botrytis, var. botrytis italica, var. costata }\end{array}$ \\
\hline Q-3,7-di-O-glycoside & var. capitata f. alba, var. acephala, var. botrytis italica \\
\hline Q-3-O-sophoroside & var. capitata f. alba, var. acephala, var. botrytis italica \\
\hline
\end{tabular}


Table 3. Cont.

\begin{tabular}{|c|c|}
\hline \multicolumn{2}{|c|}{ B-Flavonols } \\
\hline Flavonol (Q-Quercetin; K-Kaempferol) & $\begin{array}{l}\text { B. oleracea Variety Verification } \\
\text { (as Reviewed by Cartea et al. [8]) }\end{array}$ \\
\hline Q-3-O-glycoside & var. botrytis italica, var. costata \\
\hline Q-3-O-(caffeoyl)-sophorotrioside-7-O-glycoside & var. botrytis italica \\
\hline Q-3-O-(sinapoyl)-sophorotrioside-7-O-glycoside & var. botrytis italica \\
\hline Q-3-O-(feruloyl)-sophorotrioside-7-O-glycoside & var. botrytis italica \\
\hline Q-3-O-(p-coumaroyl)-sophorotrioside-7-O-glycoside & var. botrytis italica \\
\hline Q-3-O-(caffeoyl)-sophoroside-7-O-glycoside & var. capitata f. alba, var. acephala, var. botrytis italica \\
\hline Q-3-O-(methoxycaffeoyl)-sophoroside-7-O-glycoside & var. capitata f. alba, var. acephala \\
\hline Q-3-O-(sinapoyl)-sophoroside-7-O-glycoside & var. capitata f. alba, var. acephala, var. botrytis \\
\hline Q-3-O-(p-coumaroyl)-sophoroside-7-O-glycoside & var. botrytis italica \\
\hline Q-3-O-(feruloyl)-sophoroside & var. capitata f. alba, var. acephala, var. botrytis italica \\
\hline K-3-O-tetraglycoside-7-O-sophoroside & var. costata \\
\hline K-3-O-sophorotrioside-7-O-sophoroside & $\begin{array}{l}\text { var. capitata f. alba, var. acephala, } \\
\text { var. botrytis, var. botrytis italica, var. costata }\end{array}$ \\
\hline K-3-O-sohorotrioside-7-O-glycoside & var. botrytis, var. botrytis italica, var. costata \\
\hline K-3-O-sophoroside-7-O-diglycoside & var. botrytis, var. botrytis italica, var. costata \\
\hline K-3-O-sophoroside-7-O-glycoside & $\begin{array}{l}\text { var. capitata f. alba, var. acephala, } \\
\text { var. botrytis, var. botrytis italica, var. costata }\end{array}$ \\
\hline K-3,7-di-O-glycoside & var. capitata f. alba, var. acephala, var. botrytis italica \\
\hline K-3-O-sophoroside & var. capitata f. alba, var. acephala, var. botrytis italica \\
\hline K-7-O-glycoside & var. capitata f. alba, var. acephala, var. botrytis \\
\hline K-3-O-glycoside & var. botrytis italica, var. costata \\
\hline K-3-O-(caffeoyl)-sophorotrioside-7-O-sophoroside & var. botrytis italica \\
\hline K-3-O-(methoxycaffeoyl)-sophorotrioside-7-O-sophoroside & var. botrytis italica \\
\hline K-O-(sinapoyl)-sophorotrioside-7-O-sophoroside & var. botrytis italica \\
\hline K-O-(feruloyl)-sophorotrioside-7-O-sophoroside & var. botrytis italica \\
\hline K-3-O-(p-coumaroyl)-sophorotrioside-7-O-sophoroside & var. botrytis italica \\
\hline K-3-O-(caffeoyl)-sophorotrioside-7-O-glycoside & var. botrytis italica \\
\hline K-3-O-(methoxycaffeoyl)-sophorotrioside-7-O-glycoside & var. botrytis italica \\
\hline K-O-(sinapoyl)-sophorotrioside-7-O-glycoside & var. botrytis italica \\
\hline K-O-(feruloyl)-sophorotrioside-7-O-glycoside & var. botrytis italica \\
\hline K-3-O-(caffeoyl)sophoroside-7-O-glycoside & $\begin{array}{l}\text { var. capitata f. alba, var. acephala, } \\
\text { var. botrytis, var. botrytis italica, var. costata }\end{array}$ \\
\hline K-3-O-(methoxycaffeoyl)-sophoroside-7-O-glycoside & var. capitata f. alba, var. acephala, var. costata \\
\hline K-3-O-(sinapoyl)-sophoroside-7-O-glycoside & var. capitata f. alba, var. acephala, var. botrytis, var. costata \\
\hline K-3-O-(feruloyl)-sophoroside-7-O-glycoside & var. capitata f. alba, var. acephala, var. botrytis, var. costata \\
\hline K-3-O-(p-coumaroyl)-sophoroside-7-O-glycoside & var. capitata f. alba, var. acephala \\
\hline K-3-O-(methoxycaffeoyl)-sophoroside & var. capitata f. alba, var. acephala, var. botrytis italica \\
\hline K-3-O-(sinapoyl)-sophoroside & var. capitata f. alba, var. acephala, var. costata \\
\hline K-3-O-(feruloyl)-sophorotrioside & var. costata \\
\hline K-3-O-(feruloyl)-sophoroside & var. capitata f. alba, var. acephala \\
\hline K-3-O-(p-coumaroyl)-sophoroside & var. capitata f. alba, var. acephala \\
\hline
\end{tabular}

${ }^{1}$ Moreno et al. [59]; ${ }^{2}$ Scalzo et al. [47]; ${ }^{3} \mathrm{Wu}$ and Prior [46]; ${ }^{4}$ Mageney et al. (unpublished; see Supplementary Material). 
Supplementary Materials: Supplementary materials can be accessed at: http:/ /www.mdpi.com/1420-3049/22/ 2/252/s1. Table S1: Raw data of our own flavonoid quantifications on 28 kale (Brassica oleracea var. sabellica) varieties considering quercetin and kaempferol glycosides.

Acknowledgments: We would like to thank Christoph Hahn and Jan von Hacht for laboratory assistance. We also thank Reinhard Lühring for providing seeds of German landrace varieties.

Author Contributions: Dirk C. Albach and Vera Mageney conceived and designed the experiments; Susanne Neugart and Vera Mageney performed the experiments; Susanne Neugart and Vera Mageney analyzed the data; Susanne Neugart and Dirk C. Albach contributed reagents/materials/analysis tools; Vera Mageney wrote the paper, Dirk C. Albach and Susanne Neugart revised the manuscript.

Conflicts of Interest: The authors declare no conflict of interest. The founding sponsors had no role in the design of the study; in the collection, analyses, or interpretation of data; in the writing of the manuscript, and in the decision to publish the results.

\section{Appendix A}

\section{A1. Plant Material}

Plants were grown under field conditions in the botanic garden, Carl-von Ossietzky-University Oldenburg, Northern Germany $\left(53^{\circ} 9^{\prime} \mathrm{N}, 8^{\circ} 13^{\prime} \mathrm{E}\right)$ at Plaggen soil using a NPK + Mg fertilizer (12-8-16+3; $\left.80 \mathrm{~g} / \mathrm{m}^{2}\right)$ plus stone powder $\left(300 \mathrm{~g} / \mathrm{m}^{2}\right)$ directly before planted. Whole adult leaves of the second youngest rosette were harvested in December 2014 at noon, stored at $-80{ }^{\circ} \mathrm{C}$ and freeze-dried. At the date of harvest, all selected plants were 38 weeks old.

\section{A2. Flavonol and Anthocyanin Quantification}

Flavonoids were analyzed modifying the method of Schmidt et al. [11]. Lyophilized kale leafs $(0.01 \mathrm{~g})$ were extracted with $600 \mu \mathrm{L}$ of $60 \%$ aqueous methanol on a magnetic stirrer plate for $40 \mathrm{~min}$ at $20^{\circ} \mathrm{C}$ and centrifuged at $4500 \mathrm{rpm}$ for $10 \mathrm{~min}$ at same temperature and the supernatant was collected in a reaction tube. Same process was repeated twice with $300 \mu \mathrm{L}$ of $60 \%$ aqueous methanol for $20 \mathrm{~min}$ and $10 \mathrm{~min}$ respectively collecting the supernatant in the previous tube. The extract was subsequently evaporated till it was dry and suspended in $200 \mu \mathrm{L}$ of $10 \%$ aqueous methanol. Again the solvent was centrifuged at $3000 \mathrm{rpm}$ for $5 \mathrm{~min}$ at $20^{\circ} \mathrm{C}$ and filtered through Corning CostarSpin-X plastic centrifuge tube filters (Sigma Aldrich Chemical Co., St. Louis, MO, USA) for the HPLC analysis. Each extraction was carried out in duplicate.

The flavonoids composition and concentrations were determined using a series 1100 HPLC (Agilent Technologies, Waldbronn, Germany) equipped with a degasser, binary pump, autosampler, column oven and photodiode array detector to determine the hydroxycinnamic acid derivatives and glycosides of flavonols. An Ascentis Express F5 column ( $150 \mathrm{~mm} \times 4.6 \mathrm{~mm}, 5 \mu \mathrm{m}$, Supelco (Bellfonte, PA, USA)) was used to separate the compounds at $25{ }^{\circ} \mathrm{C}$. Eluent A was $0.5 \%$ acetic acid and eluent B was $100 \%$ acetonitrile. Gradient used for eluent B was 5\%-12\% (0-3 min), $12 \%-25 \%$ (3-46 min), $25-90 \%$ (46-49.5 $\mathrm{min}), 90 \%$ isocratic (49.5-52 $\mathrm{min}), 90 \%-5 \%(52-52.7 \mathrm{~min})$ and $5 \%$ isocratic (52.7-59 $\mathrm{min})$. The determination was conducted at a flow rate of $0.85 \mathrm{~mL} \cdot \mathrm{min}^{-1}$ and wavelength of $330 \mathrm{~nm}$ and $370 \mathrm{~nm}$ for acylated flavonol glycosides and non-acylated flavonol glycosides, respectively. Glycosides of flavonols were identified as deprotonated molecular ions and characteristic mass fragment ions according to Schmidt et al. [11] by high-pressure liquid chromatograpy with a diode array detector coupled to an ion-trap mass spectrometer using electrospray ionization (HPLC-DAD-ESI-MS ${ }^{n}$ ) using an Agilent series 1100 ion trap mass spectrometer (Agilent, Waldbronn, Germany) in negative ionization mode. Nitrogen was used as the dry gas $\left(10 \mathrm{~L} \cdot \mathrm{min}^{-1}, 325^{\circ} \mathrm{C}\right)$ in addition to nebulizer gas (40 psi) with a capillary voltage of $-3500 \mathrm{~V}$. Helium was used as the collision gas in the ion trap. The mass optimization for the ion optics of the mass spectrometer for quercetin was performed at $\mathrm{m} / \mathrm{z} 301$ or arbitrary at $m / z 1000$. The MS $^{n}$ experiments were performed in auto up mode by HPLC-DAD-ESI-MS ${ }^{3}$ in a scan from $\mathrm{m} / \mathrm{z}$ 200-2000. The standards, quercertin-3-glycoside, cyaniding-3-glycoside and 
kaempferol-3-glycoside (Roth, Karlsruhe, Germany) were used for external calibration curves. Results are given as $\mathrm{mg} \cdot \mathrm{g}^{-1}$ dry weight.

\section{References}

1. FAOSTAT. Available online: www.faostat3.fao.org/home/E (accessed on 5 August 2015).

2. Kushad, M.M.; Brown, A.F.; Kurilich, A.C.; Juvik, J.A.; Klein, B.P.; Wallig, M.A.; Jeffery, E.H. Variation of Glucosinolates in Vegetable Crops of Brassica oleracea. J. Agric. Food Chem. 1999, 47, 1541-1548. [CrossRef] [PubMed]

3. Koh, E.; Wimalasiri, K.; Chassy, A.; Mitchell, A. Content of ascorbic acid, quercetin, kaempferol and total phenolics in commercial broccoli. J. Food Compos. Anal. 2009, 22, 637-643. [CrossRef]

4. Agati, G.; Azzarello, E.; Pollastri, S.; Tattini, M. Flavonoids as antioxidants in plants: Location and functional significance. Plant Sci. 2012, 196, 67-76. [CrossRef] [PubMed]

5. Yao, L.H.; Jiang, Y.M.; Shi, J.; Tomás-Barberán, F.A.; Datta, N.; Singanusong, R.; Chen, S.S. Flavonoids in foods and their health benefits. Plant. Food Hum. Nutr. 2004, 59, 113-122. [CrossRef]

6. Kris-Etherton, P.; Lefevre, M.; Beecher, G.; Gross, M.; Keen, C.; Etherton, T. Bioactive compounds in nutrition and health-research methodologies for establishing biological function: The antioxidant and anti-inflammatory effects of flavonoids on atherosclerosis. Annu. Rev. Nutr. 2004, 24, 511-538. [CrossRef] [PubMed]

7. Halliwell, B.; Rafter, J.; Jenner, A. Health promotion by flavonoids, tocopherols, tocotrienols, and other phenols: Direct or indirect effects? Antioxidant or not? Am. J. Clin. Nutr. 2005, 81, 268-276.

8. Cartea, M.E.; Francisco, M.; Soengas, P.; Velasco, P. Phenolic Compounds in Brassica Vegetables. Molecules 2010, 16, 251-280. [CrossRef] [PubMed]

9. Erdman, J.W., Jr.; Balentine, D.; Arab, L.; Arab, L.; Beecher, G.; Dwyer, J.T.; Folts, J.; Harnly, J.; Hollman, P.; Keen, C.L.; et al. Flavonoids and Heart Health: Proceedings of the ILSI North America Flavonoids Workshop, 31 May-1 June 2005, Washington, DC. J. Nutr. 2007, 137, 718-737.

10. Zietz, M.; Annika, W.; Schmidt, S.; Rohn, S.; Schreiner, M.; Krumbein, A.; Kroh, L.W. Genotypic and Climatic Influence on the Antioxidant Activity of Flavonoids in Kale (Brassica oleracea var. sabellica). J. Agric. Food Chem. 2010, 58, 2123-2130. [CrossRef] [PubMed]

11. Schmidt, S.; Zietz, M.; Schreiner, M.; Rohn, S.; Kroh, L.W.; Krumbein, A. Genotypic and climatic influences on the concentration and composition of flavonoids in kale (Brassica oleracea var. sabellica). Food Chem. 2010, 119, 1293-1299. [CrossRef]

12. Reilly, K.; Valverde, J.; Finn, L.; Rai, D.K.; Brunton, N.; Sorensen, J.C.; Sorensen, H.; Gaffney, M. Potential of cultivar and crop management to affect phytochemical content in winter-grown sprouting broccoli (Brassica oleracea L var. italica). J. Sci. Food Agric. 2013, 94, 322-330. [CrossRef] [PubMed]

13. Sousa, C.; Lopes, G.; Pereira, D.; Taveira, M.; Valentao, P.; Seabra, R.; Pereira, J.; Baptista, P.; Ferreres, F.; Andrade, P. Screening of Antioxidant Compounds During Sprouting of Brassica oleracea L. var. costata DC. Comb. Chem. High Throughput Screen. 2007, 10, 377-386. [CrossRef] [PubMed]

14. Šamec, D.; Piljac-Žegarac, J.; Bogović, M.; Habjanič, K.; Grúz, J. Antioxidant potency of white (Brassica oleracea $\mathrm{L}$ var. capitata) and Chinese (Brassica rapa $\mathrm{L}$ var. pekensis (Lour)) cabbage: The influence of development stage, cultivar choice and seed selection. Sci. Hort. 2011, 128, 78-83.

15. Soengas, P.; Cartea, M.; Francisco, M.; Sotelo, T.; Velasco, P. New insights into antioxidant activity of Brassica crops. Food Chem. 2012, 134, 725-733. [CrossRef] [PubMed]

16. Sousa, C.; Pereira, D.M.; Pereira, J.A.; Bento, A.; Rodrigues, M.A.; Dopico-Garcia, A.; Valentão, P.; Lopes, G.; Ferreres, F.; Seabra, R.M.; et al. Multivariate Analysis of Tronchuda Cabbage (Brassica oleracea L var. costata DC) Phenolics: Influence of Fertilizers. J. Agric. Food Chem. 2008, 56, 2231-2239. [PubMed]

17. Sousa, C.; Valentão, P.; Ferreres, F.; Seabra, R.M.; Andrade, P.B. Tronchuda Cabbage (Brassica oleracea L var var costata DC): Scavenger of Reactive Nitrogen Species. J. Agric. Food Chem. 2008, 56, 4205-4211. [CrossRef] [PubMed]

18. Treutter, D. Significance of flavonoids in plant resistance: A review. Environ. Chem. Lett. 2006, 4, 147-157. [CrossRef] 
19. Ferrieri, A.P.; Appel, H.M.; Schultz, J.C. Plant Vascular Architecture Determines the Pattern of Herbivore-Induced Systemic Responses in Arabidopsis thaliana. PLoS ONE 2015, 10, e0123899. [CrossRef] [PubMed]

20. Fallovo, C.; Schreiner, M.; Schwarz, D.; Colla, G.; Krumbein, A. Phytochemical changes induced by different nitrogen supply forms and radiation levels in two leafy Brassica species. J. Agric. Food Chem. 2011, 59, 4198-4207. [CrossRef] [PubMed]

21. Neugart, S.; Fiol, M.; Schreiner, M.; Rohn, S.; Zrenner, R.; Kroh, L.W.; Krumbein, A. Low and moderate photosynthetically active radiation affects the flavonol glycosides and hydroxycinnamic acid derivatives in kale (Brassica oleracea var. sabellica) dependent on two low temperatures. Plant Physiol. Biochem. 2013, 72, 161-168. [PubMed]

22. Neugart, S.; Zietz, M.; Schreiner, M.; Rohn, S.; Kroh, L.W.; Krumbein, A. Structurally different flavonol glycosides and hydroxycinnamic acid derivatives respond differently to moderate UV-B radiation exposure. Physiol. Plant 2012, 145, 582-593. [CrossRef] [PubMed]

23. Naguib, A.E.-M.M.; El-Baz, F.K.; Salama, Z.A.; Hanaa, H.A.E.B.; Ali, H.F.; Gaafar, A.A. Enhancement of phenolics, flavonoids and glucosinolates of Broccoli (Brassica olaracea var. italica) as antioxidants in response to organic and bio-organic fertilizers. J. Saudi Soc. Agric. Sci. 2012, 11, 135-142.

24. Valverde, J.; Reilly, K.; Villacreces, S.; Gaffney, M.; Grant, J.; Brunton, N. Variation in bioactive content in broccoli (Brassica oleracea var. italica) grown under conventional and organic production systems. J. Sci. Food Agric. 2014, 95, 1163-1171. [PubMed]

25. Groenbaek, M.; Jensen, S.; Neugart, S.; Schreiner, M.; Kidmose, U.; Kristensen, H.L. Influence of Cultivar and Fertilizer Approach on Curly Kale (Brassica oleracea L. var. sabellica). 1. Genetic Diversity Reflected in Agronomic Characteristics and Phytochemical Concentration. J. Agric. Food Chem. 2014, 62, 11393-11402. [PubMed]

26. Pęal, A.; Pyrzynska, K. Evaluation of Aluminium Complexation Reaction for Flavonoid Content Assay. Food Anal. Methods 2014, 7, 1776-1782. [CrossRef]

27. Hagen, S.F.; Borge, G.I.A.; Solhaug, K.A.; Bengtsson, G.B. Effect of cold storage and harvest date on bioactive compounds in curly kale (Brassica oleracea L var. acephala). Postharvest Biol. Technol. 2009, 51, 36-42. [CrossRef]

28. Vallejo, F.; Tomás-Barberán, F.; García-Viguera, C. Health-Promoting Compounds in broccoli as Influenced by Refrigerated Transport and Retail Sale Period. J. Agric. Food Chem. 2003, 51, 3029-3034. [CrossRef] [PubMed]

29. Bahorun, T.; Luximon-Ramma, A.; Crozier, A.; Aruoma, O.I. Total phenol, flavonoid, proanthocyanidin and vitamin C levels and antioxidant activities of Mauritian vegetables. J. Sci. Food Agric. 2004, 84, 1553-1561. [CrossRef]

30. Heimler, D.; Vignolini, P.; Dini, M.G.; Vincieri, F.F.; Romani, A. Antiradical activity and polyphenol composition of local Brassicaceae edible varieties. Food Chem. 2006, 99, 464-469. [CrossRef]

31. Jacob, J.A.; Mahal, H.; Mukherjee, T.; Kapoor, S. Free radical reactions with the extract of brassica family. Food Chem. 2011, 129, 1132-1138. [CrossRef] [PubMed]

32. Jaiswal, A.K.; Abu-Ghannam, N.; Gupta, S. A comparative study on the polyphenolic content, antibacterial activity and antioxidant capacity of different solvent extracts of Brassica oleracea vegetables. Int. J. Food Sci. Technol. 2011, 47, 223-231. [CrossRef]

33. Lola-Luz, T.; Hennequart, F.; Gaffney, M. Effect on yield, total phenolic, total flavonoid and total isothiocyanate content of two broccoli cultivars (Brassica oleracea var. italica) following the application of a commercial brown seaweed extract (Ascophyllum. nodosum). Agric. Food Sci. 2014, 23, $28-37$.

34. Strack, D. Phenolic compounds. In Plant Biochemistry, 1st ed.; Dey, P., Harborne, J., Eds.; Academic Press: San Diego, CA, USA, 1997; pp. 387-416.

35. Pollastri, S.; Tattini, M. Flavonols: Old compounds for old roles. Ann. Bot. 2011, 108, 1225-1233. [CrossRef] [PubMed]

36. Hollman, P.C.; Arts, I.C. Flavonols, flavones and flavanols-Nature, occurrence and dietary burden. J. Sci. Food Agric. 2000, 80, 1081-1093. [CrossRef]

37. Beecher, G.R. Overview of dietary flavonoids: Nomenclature, occurrence and intake. J. Nutr. 2003, 133, 3248S-3254S. [PubMed]

38. Heim, K.E.; Tagliaferro, A.R.; Bobilya, D.J. Flavonoid antioxidants: Chemistry, metabolism and structure-activity relationships. J. Nutr. Biochem. 2002, 13, 572-584. [CrossRef] 
39. Podsedek, A. Natural antioxidants and antioxidant capacity of Brassica vegetables: A review. LWT-Food Sci. Technol. 2007, 40, 1-11. [CrossRef]

40. Winkel-Shirley, B. Biosynthesis of flavonoids and effects of stress. Curr. Opin. Plant Biol. 2002, 5, $218-223$. [CrossRef]

41. Ponce, MA.; Scervino, J.M.; Erra-Balsells, R.; Ocampo, J.A.; Godeas, A.M. Flavonoids from shoots, roots and roots exudates of Brassica alba. Phytochemistry 2004, 65, 3131-3134. [CrossRef] [PubMed]

42. Martens, S.; Mithöfer, A. Flavones and flavone synthases. Phytochemistry 2005, 66, 2399-2407. [CrossRef] [PubMed]

43. Sakakibara, H.; Honda, Y.; Nakagawa, S.; Ashida, H.; Kanazawa, K. Simultaneous Determination of All Polyphenols in Vegetables, Fruits, and Teas. J. Agric. Food Chem. 2003, 51, 571-581. [CrossRef] [PubMed]

44. Miean, K.H.; Mohamed, S. Flavonoid (Myricetin, Quercetin, Kaempferol, Luteolin, and Apigenin) Content of Edible Tropical Plants. J. Agric. Food Chem. 2001, 49, 3106-3112. [CrossRef] [PubMed]

45. Cao, J.; Chen, W.; Zhang, Y.; Zhang, Y.; Zhao, X. Content of Selected Flavonoids in 100 Edible Vegetables and Fruits. Food Sci. Technol. Res. 2010, 16, 395-402. [CrossRef]

46. Wu, X.; Prior, R.L. Identification and Characterization of Anthocyanins by High-Performance Liquid Chromatography-Electrospray Ionization-Tandem Mass Spectrometry in Common Foods in the United States: Vegetables, Nuts, and Grains. J. Agric. Food Chem. 2005, 53, 3101-3113. [CrossRef] [PubMed]

47. Scalzo, R.L.; Genna, A.; Branca, F.; Chedin, M.; Chassaigne, H. Anthocyanin composition of cauliflower (Brassica oleracea L var. botrytis) and cabbage (B. oleracea L var. capitata) and its stability in relation to thermal treatments. Food Chem. 2008, 107, 136-144.

48. Philips, D.A.; Kapulnik, Y. Plant isoflavonoids, pathogens and symbionts. Trends Microbiol. 1995, 58, 58-64. [CrossRef]

49. Kuhnle, G.G.; Dell'Aquila, C.; Aspinall, S.M.; Runswick, S.A.; Joosen, A.M.; Mulligan, A.A.; Bingham, S.A. Phytoestrogen content of fruits and vegetables commonly consumed in the UK based on LC-MS and ${ }^{13}$ C-labelled standards. Food Chem. 2009, 116, 542-554. [CrossRef]

50. Olsen, H.; Aaby, K.; Borge, G.I.A. Characterization and Quantification of Flavonoids and Hydroxycinnamic Acids in Curly Kale (Brassica oleracea L convar. acephala var. sabellica) by HPLC-DAD-ESI-MS ${ }^{n}$. J. Agric. Food Chem. 2009, 57, 2816-2825. [PubMed]

51. Rice-Evans, C.A.; Miller, N.J.; Paganga, G. Structure-antioxidant activity relationships of flavonoids and phenolic acids. Free Radic. Biol. Med. 1996, 20, 933-956. [CrossRef]

52. Tabart, J.; Kevers, C.; Pincemail, J.; Defraigne, J.-O.; Dommes, J. Comparative antioxidant capacities of phenolic compounds measured by various tests. Food Chem. 2009, 113, 1226-1233. [CrossRef]

53. Vallejo, F.; Tomás-Barberán, F.; Ferreres, F. Characterisation of flavonols in broccoli (Brassica oleracea L var. italica) by liquid chromatography-UV diode-array detection-electrospray ionisation mass spectrometry. J. Chromatogr. A 2004, 1054, 181-193. [PubMed]

54. Lin, L.-Z.; Harnly, J.; Zhang, R.-W.; Fan, X.-E.; Chen, H.-J. Quantitation of the Hydroxycinnamic Acid Derivatives and the Glycosides of Flavonols and Flavones by UV Absorbance after Identification by LC-MS. J. Agric. Food Chem. 2012, 60, 544-553. [CrossRef] [PubMed]

55. Neugart, S.; Fiol, M.; Schreiner, M.; Rohn, S.; Zrenner, R.; Kroh, L.W.; Krumbein, A. Interaction of Moderate UV-B Exposure and Temperature on the Formation of Structurally Different Flavonol Glycosides and Hydroxycinnamic Acid Derivatives in Kale (Brassica oleracea var. sabellica). J. Agric. Food Chem. 2014, 62, 4054-4062. [CrossRef] [PubMed]

56. Neugart, S.; Krumbein, A.; Zrenner, R. Influence of Light and Temperature on Gene Expression Leading to Accumulation of Specific Flavonol Glycosides and Hydroxycinnamic Acid Derivatives in Kale (Brassica oleracea var. sabellica). Front. Plant Sci. 2016, 7, 326. [CrossRef] [PubMed]

57. Pliszka, B.; Huszcza-Ciołkowska, G.; Mieleszko, E.; Czaplicki, S. Stability and antioxidative properties of acylated anthocyanins in three cultivars of red cabbage (Brassica oleracea L. var. capitata L. f. rubra). J. Sci. Food Agric. 2009, 89, 1154-1158. [CrossRef]

58. Julkunen-Tiitto, R.; Nenadis, N.; Neugart, S.; Robson, M.; Agati, G.; Vepsäläinen, J.; Zipoli, G.; Nybakken, L.; Winkler, B.; Jansen, M.A.K. Assessing the response of plant flavonoids to UV radiation: An overview of appropriate techniques. Phytochem. Rev. 2014, 14, 273-297. [CrossRef]

59. Moreno, D.A.; Pérez-Balibrea, S.; Ferreres, F.; Gil-Izquierdo, Á.; García-Viguera, C. Acylated anthocyanins in broccoli sprouts. Food Chem. 2010, 123, 358-363. [CrossRef] 
60. Sikora, E.; Cieślik, E.; Filipiak-Florkiewicz, A.; Leszczyńska, T. Effect of hydrothermal processing on phenolic acids and flavonols contents in selected Brassica vegetables. Acta Sci. Pol. Technol. Aliment. 2012, 11, 45-51. [PubMed]

61. Mazur, W.; Adlercreutz, H. Natural and anthropogenic environmental oestrogens: The scientific basis for risk assessment. Pure Appl. Chem. 1998, 70, 1759-1776. [CrossRef]

62. Lapcik, O.; Honys, D.; Koblovska, R.; Mackova, Z.; Vitkova, M.; Klejdus, B. Isoflavonoids are present in Arabidopsis thaliana despite the absence of any homologue to known isoflavonoid synthases. Plant Physiol. Biochem. 2006, 44, 106-114. [CrossRef] [PubMed]

(C) 2017 by the authors; licensee MDPI, Basel, Switzerland. This article is an open access article distributed under the terms and conditions of the Creative Commons Attribution (CC BY) license (http:/ / creativecommons.org/licenses/by/4.0/). 